\title{
Pengaruh Model Pembelajaran Kooperatif Tipe Team Games Tournament Berbantuan Peta Konsep Terhadap Hasil Belajar IPA
}

\author{
Putu Hermayanti ${ }^{*}$, Made Sumantri², I Komang Sudarma ${ }^{3}$
}

Jurusan Pendidikan Guru Sekolah Dasar (PGSD), Universitas Pendidikan Ganesha, Singaraja, Indonesia.

\author{
A R T I C L E I N F O \\ Article history: \\ Received 21 February 2018 \\ Received in revised form \\ 6 March 2018 \\ Accepted 19 April 2018 \\ Available online 29 May \\ 2018 \\ Kata Kunci: \\ team games tournament, \\ peta konsep, hasil belajar \\ IPA. \\ Keywords: \\ team games tournament, \\ concept map, learning \\ result.
}

\begin{abstract}
A B S T R A K
Penelitian ini bertujuan untuk mengetahui adanya perbedaan hasil belajar IPA antara kelompok siswa yang dibelajarkan dengan model pembelajaran kooperatif tipe Team Games Tournament (TGT) berbantuan peta konsep dan kelompok siswa yang dibelajarkan dengan model konvensional pada siswa kelas V semester II di Gugus VI Kecamatan Sukasada, Kabupaten Buleleng tahun pelajaran 2016/2017. Desain penelitian yang digunakan adalah non equivalent posttest-only control group design. Populasi dalam penelitian ini adalah seluruh siswa kelas V SD GugusV I Kecamatan Sukasada, Kabupaten Buleleng. Penentuan sampel dilakukan dengan teknik random sampling, sehingga didapatkan dua kelas yaitu kelas V SD Negeri 2 Panji Anom berjumlah 33 siswa sebagai kelas eksperimen dan siswa kelas V SD Negeri 4 Panji Anom berjumlah 30 siswa sebagai kelas kontrol. Instrumen pengumpulan data pada penelitian ini adalah tes pilihan ganda (objektif) dengan dua tahap analisis yaitu analisis statisik deskriptif dan analisis statistik inferensial (Uji-t). Hasil penelitian ini yaitu, diperoleh perhitungan uji-t, thitung $=14,4>$ ttabel $=1,98$ (dengan $\mathrm{db} 61$ dan taraf signifikansi $5 \%$ ), sehingga $\mathrm{H} 0$ ditolak dan $\mathrm{H} 1$ diterima. Dengan demikian dapat dinyatakan bahwa model pembelajaran kooperatif tipe Team Games Tournament (TGT) berbantuan peta konsep berpengaruh signifikan terhadap hasil belajar IPA siswa kelas V di Gugus VI Kecamatan Sukasada Kabupaten Buleleng Tahun Pelajaran 2016/2017
\end{abstract}

\section{A B S T RACT}

This study aims to determine the differences of science learning outcomes between groups of students who were taught by cooperative learning model of Team Games Tournament (TGT) type assisted concept maps and groups of students who were taught by conventional model in V grade II students in Gugus VI Kecamatan Sukasada, Kabupaten Buleleng academic year 2016/2017. The research design used is non equivalent posttest-only control group design. The population in this study is all students of grade V SD GugusV I Sukasada District, Buleleng District. Determination of sample is done by random sampling technique, so that got two classes that is class V SD Negeri 2 Panji Anom amounted to 33 students as experiment class and class V student of SD Negeri 4 Panji Anom amounted 30 student as control class. The instrument of data collection in this research is multiple choice test (objective) with two stages of analysis that is descriptive static analysis and inferential statistical analysis (t-test). The result of this research is t-test, tct $=14,4>$ ttable $=1,98$ (with $\mathrm{db} 61$ and significance level $5 \%$ ), so $\mathrm{H} 0$ is rejected and $\mathrm{H} 1$ accepted. Thus, it can be stated that cooperative learning model of Team Games Tournament type (TGT) with concept map has significant effect on science learning outcomes of class V students in Gugus VI Sukasada Sub-district of Buleleng Regency in the Lesson Year 2016/2017. 


\section{Pendahuluan}

Ilmu Pengetahuan Alam (IPA) adalah ilmu yang mempelajari peristiwa-peristiwa yang terjadi di alam dengan melakukan observasi, eksperimentasi, penyimpulan, dan penyusunan teori agar siswa mempunyai pengetahuan, gagasan dan kosep yang terorganisasi tentang alam sekitar, yang diperoleh dari pengalaman melalui serangkain proses ilmiah. Dawson (dalam Bundu, 2006:10) menyatakan bahwa, IPA juga merupakan aktivitas pemecahan masalah oleh manusia yang termotivasi oleh keingintahuan akan alam disekelilingnya dan keinginan untuk memahami, menguasai, dan mengolahnya demi memenuhi kebutuhan. Bundu (2006:11), secara garis besar, "IPA memiliki tiga komponen yakni sebagai produk, proses dan sikap ilmiah". IPA sebagai produk merupakan kumpulan kegiatan empirik dan kegiatan analitik yang dilakukan para ilmuan selama berabad-abad. Bentuk IPA sebagai produk adalah fakta-fakta, konsep-konsep, prinsip-prinsip, dan teori-teori IPA. IPA sebagai proses adalah bagaimana mengumpulkan fakta-fakta dan bagaimana menghubungkan fakta-fakta untuk menginterpretasikannya. Terdapat beberapa keterampilan proses IPA diantaranya adalah mengamati, mengukur, menarik kesimpulan, mengendalikan variabel, merumuskan hipotesis, membuat grafik dan tabel data, membuat definisi operasional, dan melakukan eksperimen. Aspek ketiga dari IPA adalah sikap ilmiah. Sikap ilmiah adalah sikap yang dimiliki para ilmuan dalam mencari dan mengembangkan pengetahuan baru, misalnya obyektif terhadap fakta, hati-hati, tanggung jawab, berhati terbuka, selalu ingin meneliti, dan sikap ingin tahu. Putra (2017) menyatakan, "pembelajaran IPA di sekolah dasar sebaiknya memberikan kebebasan siswa untuk membuat atau menafsirkan suatu hal dalam kegiatan pembelajarannya untuk merancang dan menemukan sesuatu secara mandiri".

Tujuan IPA secara umum adalah membantu siswa untuk mengembangkan pengetahuan dan pemahaman konsep-konsep IPA yang akan bermanfaat dan dapat diterapkan dalam kehidupan seharihari. Melalui pendidikan IPA diharapkan dapat menumbuhkan kemampuan berpikir logis, rasional, analisis, dan kritis pada siswa dalam rangka mendukung perkembangan ilmu pengetahuan dan teknologi. Sehubungan dengan hal tersebut, dalam proses pembelajaran di sekolah khususnya di sekolah dasar, seorang guru harus mampu menggunakan model-model pembelajaran yang inovatif, metode yang bervariasi dan penggunaan media yang tepat, agar siswa lebih aktif dan kreatif dalam mengikuti proses pembelajaran, dan apa yang menjadi tujuan dalam pembelajaran dapat tercapai sesuai dengan yang diharapkan.

Sukardjo (2012) kaitannya dengan pembelajaran, menurut teori konstruktivisme yang menjadi dasar bahwa siswa memperoleh pengetahuan adalah karena keaktifan siswa itu sendiri. Konsep teori pembelajaran menurut teori kontruktivisme adalah suatu proses pembelajaran yang mengkondisikan siswa untuk melakukan proses aktif membangun konsep baru, pengertian baru, dan pengetahuan baru berdasarkan data. Oleh karena itu, proses pembelajaran harus dirancang dan dikelola sedemikian rupa sehingga mampu mendorong siswa mengorganisasi pengalamannya sendiri menjadi pengetahuan yang bermakna. Guru dituntut untuk menjadi guru yang profesional dalam hal merancang, melaksanakan, dan mengevaluasi pembelajaran. "Guru harus melaksanakan pembelajaran yang tepat dan benar dengan menggunakan berbagai startegi, pendekatan, metode dan media yang sesuai dengan karakteristik perkembangan siswa, lingkungan siswa dan materi pembelajaran."(Sudarmi, 2014).

Berdasarkan observasi yang dilakukan di Gugus VI Kecamatan Sukasada dengan guru kelas V diperoleh informasi tentang masalah yang dihadapi dalam pelaksanaan pembelajaran IPA. Dalam pelaksanaan pembelajaran IPA guru cenderung menyampaikan materi pembelajaran dengan metode ceramah tanpa menggunakan model pembelajaran. Hal ini dapat dilihat dari kegiatan pembelajaran di dalam kelas yang selalu didomonasi oleh guru dan kurangnya penggunaan media dalam proses pembelajaran. Dalam penyampaian materi guru hanya menggunakan metode ceramah yang dalam pelaksanaannya siswa hanya duduk, mencatat, dan mendengarkan apa yang disampaikan guru dan sedikit peluang bagi siswa untuk bertanya. Dengan demikian, suasana pembelajaran menjadi tidak kondusif sehingga siswa menjadi pasif. Jika siswa kurang tertarik dengan model yang digunakan guru, maka dengan sendirinya siswa akan memberikan umpan balik yang kurang mendukung dalam proses pembelajaran. Akibatnya adalah timbul rasa tidak simpati terhadap guru, tidak tertarik dengan materi-materi pelajaran, dan lama kelamaan timbul sikap acuh tak acuh terhadap mata pelajaran. Hal ini akan berpengaruh pada hasil belajar IPA siswa.

Salah satu upaya yang dapat dilakukan untuk meningkatkan hasil belajar siswa khususnya pada mata pelajaran IPA adalah menggunakan model pembelajaran yang inovatif dan menyenangkan. Model pembelajaran yang tepat dalam proses pembelajaran dapat menjadikan siswa merasa tertarik untuk mengikuti pembelajaran di kelas. Salah satu model pembelajaran yang inovatif dan menyenangkan adalah model pembelajaran kooperatif tipe Team Games Tournament (TGT). Slavin (2010:163), Team Games Tournament (TGT) merupakan, "Pembelajaran kooperatif yang menggunakan tournamen akademik, dan 
menggunakan kuis-kuis dan sistem skor kemajuan individu, dimana para siswa berlomba sebagai wakil tim mereka dengan anggota tim lain yang kinerja akademik sebelumnya setara seperti mereka". Selain itu, aktivitas belajar dengan permainan yang dirancang dalam pembelajaran kooperatif model TGT memungkinkan siswa dapat belajar lebih rileks di samping menumbuhkan tanggung jawab, kerja sama, persaingan sehat, dan keterlibatan belajar.

Namun, jika hanya model yang baik tanpa didukung oleh media yang tepat, tujuan pembelajaran tidak pula dapat tercapai maksimal. Agar model pembelajaran dapat berjalan secara efektif dan efesien, maka digunakan peta konsep sebagai media pembelajaran. Dengan peta konsep, siswa akan mengingat banyak informasi yang mereka tulis karena peta konsep menggunakan konsep-konsep atau ide-ide pokok yang saling berhubungan antara satu dengan yang lainnya. Makna dari beberapa konsep akan mudah dipahami dengan melihat hubungan antara satu konsep dengan konsep yang lainnya. Tidak hanya itu, peta konsep yang berbentuk bagan akan menimbulkan ketertarikan atau perhatian yang menyebabkan timbulnya rasa senang pada diri siswa.

Berdasarkan pemaparan di atas, tujuan penelitian ini adalah untuk mengetahui perbedaan hasil belajar IPA antara kelompok siswa yang dibelajarkan dengan model pembelajaran kooperatif tipe Team Games Tournament (TGT) berbantuan peta konsep dan kelompok siswa yang dibelajarkan dengan model pembelajaran konvensional pada siswa kelas V SD di Gugus VI Kecamatan Sukasada Kabupaten Buleleng tahun pelajaran 2016/2017.

\section{Metode}

Penelitian ini dilaksanakan di SD Gugus VI Kecamatan Sukasada Tahun Pelajaran 2016/2017. Jenis penelitian yang dilakukan termasuk jenis penelitian quasi eksperiment (Eksperimen Semu) dengan desain non-equivalent posttest only control group design. Populasi penelitian ini adalah seluruh siswa kelas $V$ di Gugus VI Kecamatan Sukasada Kabupaten Buleleng. Untuk mengetahui kemampuan siswa kelas V masingmasing SD yang terdapat di Gugus VI Kecamatan Sukasada setara atau belum, maka terlebih dahulu dilakukan uji kesetaraan. Uji kesetaraan dilakukan dengan menganalisis hasil belajar IPA dengan menggunakan nilai ulangan tengah semester. Uji kesetaraan dilakukan dengan menggunakan uji ANAVA satu jalur dan diperoleh ke tujuh SD kelas V tersebut memiliki kemampuan yang setara.

Setelah semua kelas dinyatakan setara, maka dilanjutkan dengan penentuan sampel penelitian. Penentuan sampel menggunakan random sampling, dengan teknik undian. Semua nama sekolah di gugus VI Kecamatan Sukasada ditulis dalam kertas kecil, kemudian digulung. Selanjutnya peneliti memilih dua gulungan kertas secara acak. Hasil dari pengundian itu digunakan sebagai sampel dalam penelitian, setelah melakukan pengundian untuk sampel penelitian dilanjutkan dengan pemilihan kelas eksperimen dan kelas control. Untuk mencari kelas eksperimen dan kelas konntrol dilakukan undian yang sama seperti mengundi sampel penelitian, yaitu menulis kedua nama sekolah dalam kertas kecil, kemudian digulung. Selanjutnya peneliti mengambil gulungan kertas pertama yang akan dijadikan sebagai kelas eksperimen dan gulungan kertas kedua sebagai kelas kontrol.

Berdasarkan teknik tersebut terpilih seluruh siswa kelas V SD N 2 Panji Anom sebagai kelas eksperimen dan seluruh siswa kelas V SD N 4 Panji Anom sebagai kelas kontrol. Kelompok eksperimen diberikan materi dengan menggunakan model pembelajaran kooperatif tipe Team Games Tournament (TGT) berbantuan peta konsep, sedangkan kelompok kontrol diberikan materi dengan menggunakan model pembelajaran konvensional.

Salah satu faktor yang mempengaruhi hasil penelitian adalah validitas internal. Validitas internal merupakan salah satu kualitas pelaksanaan penelitian terhadap hasil belajar. Hal tersebut sesuai dengan pendapat Dantes (2012) yang menyatakan, validitas internal menyangkut tingkat kualitas dan ketepatan pelaksanaan penelitian dalam penggunaan berbagai instrumen yang menunjukkan sejauh mana hasil yang terjadi pada variabel terobservasi merupakan akibat dari variabel bebas. Berikutnya menurut Setyosari (2015), faktor-faktor yang dapat mempengaruhi validitas internal pada penelitian ini meliputi, sejarah (history), kematangan atau maturasi (maturation), pengaruh penggunaan instrument (instrumentation), moralitas (mortality), dan seleksi kelompok.

Selain faktor internal, ada faktor lain yang bersifat eksternal yang memiliki pengaruh pada hasil penelitiannya yaitu validitas eksternal. Validitas eksternal dalam penelitian sangat mempengaruhi suatu hasil penelitian itu sendiri. Menurut Dantes (2012), validitas eksternal menyangkut kualitas sejauh mana suatu hasil penelitian dapat digeneralisasikan. Menurut Setyosari (2015:180) menyatakan, "Validitas eksternal bersumber dari luar penelitian yang kita lakukan". Beberapa ancaman yang berkaitan dengan validitas eksternal ini meliputi: interaksi antara perlakuan dan orang, interaksi antara perlakuan dan 
latar, dan interaksi antara perlakuan dan waktu. Istilah interaksi merupakan suatu kombinasi perlakuan dengan orang, latar dan waktu bukannya dengan perlakuan itu sendiri yang menyebabkan perbedaan hasil. Cara yang dapat dilakukan untuk mengontrol validitas eksternal yaitu dengan menunjukkan melalui pengamatan dan wawancara secara kualitatif yang menyatakan bahwa tidak ada orang-orang dan latar tertentu atau khusus dan peristiwa-peristiwa historis yang akan dapat menghambat generalisasi hasil penelitian.

Data yang ingin diketahui dalam penelitian ini adalah hasil belajar IPA siswa melalui post-test setelah diberikannya perlakuan pada mata pelajaran IPA khususnya dikelas V. Metode tes dilakukan dengan membagikan jumlah tes untuk mengukur hasil belajar IPA siswa dengan menggunakan model pembelajaran kooperatif tipe Team Games Tournament untuk kelompok belajar eksperimen berbantuan peta konsep dan pembelajaran konvensional untuk kelompok kontrol.

Fokus data yang dicari dalam penelitian ini ialah data hasil belajar IPA. Instrumen yang digunakan dalam proses pengumpulan data ini ialah tes hasil belajar pada ranah kognitif. Menurut Agung (2014:92), metode tes dalam kaitannya dengan penelitian ialah, "Cara memperoleh data yang berbentuk suatu tugas yang dilakukan atau dikerjakan oleh seseorang atau kelompok orang yang dites, dan dari tes tersebut dapat menghasilkan suatu data berupa skor". Dalam hal ini, digunakan tes objektif dalam bentuk pilihan ganda yang terdiri dari empat alternatif pilihan jawaban. Uji coba instrumen bertujuan untuk mengetahui apakah instrumen tersebut layak atau tidaknya digunakan. Dalam penelitian ini, yang di uji coba instrumennya adalah hasil belajar IPA namun untuk mengetahui layak atau tidaknya suatu instrumen maka instrumen tersebut perlu di uji coba dengan uji validitas butir soal, reabilitas tes, taraf kesukaran tes, dan uji daya beda.

Teknik analisis data dalam penelitian ini menggunakan statistik deskriptif dan statistik inferensial. Teknik analisis deskriptif yang digunakan adalah rata-rata (M), median (Md), modus (Mo), standar deviasi (SD) dan varians (s2). Uji prasyarat juga sangat penting untuk mengetahui apakah analisis data untuk pengujian hipotesis dapat dilanjutkan atau tidak. Uji prasyarat analisis meliputi uji normalitas sebaran data dan uji homogenitas varians.

Karena $\mathrm{n} 1 \neq \mathrm{n} 2$ dan hasil varians menyatakan homogen, maka dalam pengujian hipotesis dapat digunakan rumus t-test dengan polled varians, dengan derajat kebebasan $(n 1+n 2)-2$. Kriteria pengujian, terima Ho jika thitung $\leq$ ttabel dan tolak Ho jika thitung $\geq$ ttabel dengan harga t pengganti ttabel dihitung selisih dari harga ttabel, dengan $\mathrm{db}=(\mathrm{n} 1-1)$ dan $\mathrm{db}(\mathrm{n} 2-1)$, dibagi dua, kemudian ditambah dengan harga $t$ yang terkecil.

\section{Hasil dan Pembahasan}

Analisis deskriptif dilakukan untuk mengetahui tinggi rendahnya hasil belajar siswa, baik siswa yang belajar mengikuti model pembelajaran kooperatif Tipe Team Games Tournament berbantuan peta konsep dan siswa yang belajar mengikuti model pembelajaran konvensional. Rekapitulasi perhitungan skor hasil belajar siswa disajikan pada Tabel 1.

Tabel 1. Rekapitulasi Perhitungan Skor Hasil Belajar Siswa

\begin{tabular}{lll}
\hline \multirow{2}{*}{$\begin{array}{ll}\text { Data } \\
\text { Statistik }\end{array}$} & \multicolumn{2}{l}{ Hasil Belajar Siswa } \\
\cline { 2 - 3 } & Kelas Eksperimen & Kelas Kontrol \\
\hline Mean & 23,03 & 19,83 \\
Median & 24,00 & 19,60 \\
Modus & 24,11 & 18,5 \\
\hline
\end{tabular}

Bedasarkan Tabel 1 dapat dideskripsikan mean (M), median (Md), modus (Mo) dari data hasil belajar siswa kelas eksperimen, yaitu: mean $(M)=23,03$, median $(M d)=24,00$, modus $(\mathrm{Mo})=24,11$. Pada kelas eksperimen diketahui bahwa modus lebih besar dari median dan median lebih besar dari mean (Mo $>\mathrm{Md}>\mathrm{M}$ ), sehingga kurva yang terbentuk adalah adalah kurva juling negatif yang artinya skor cenderung tinggi. Grafik data hasil belajar eksperimen dapat dilihat pada Gambar 1. 


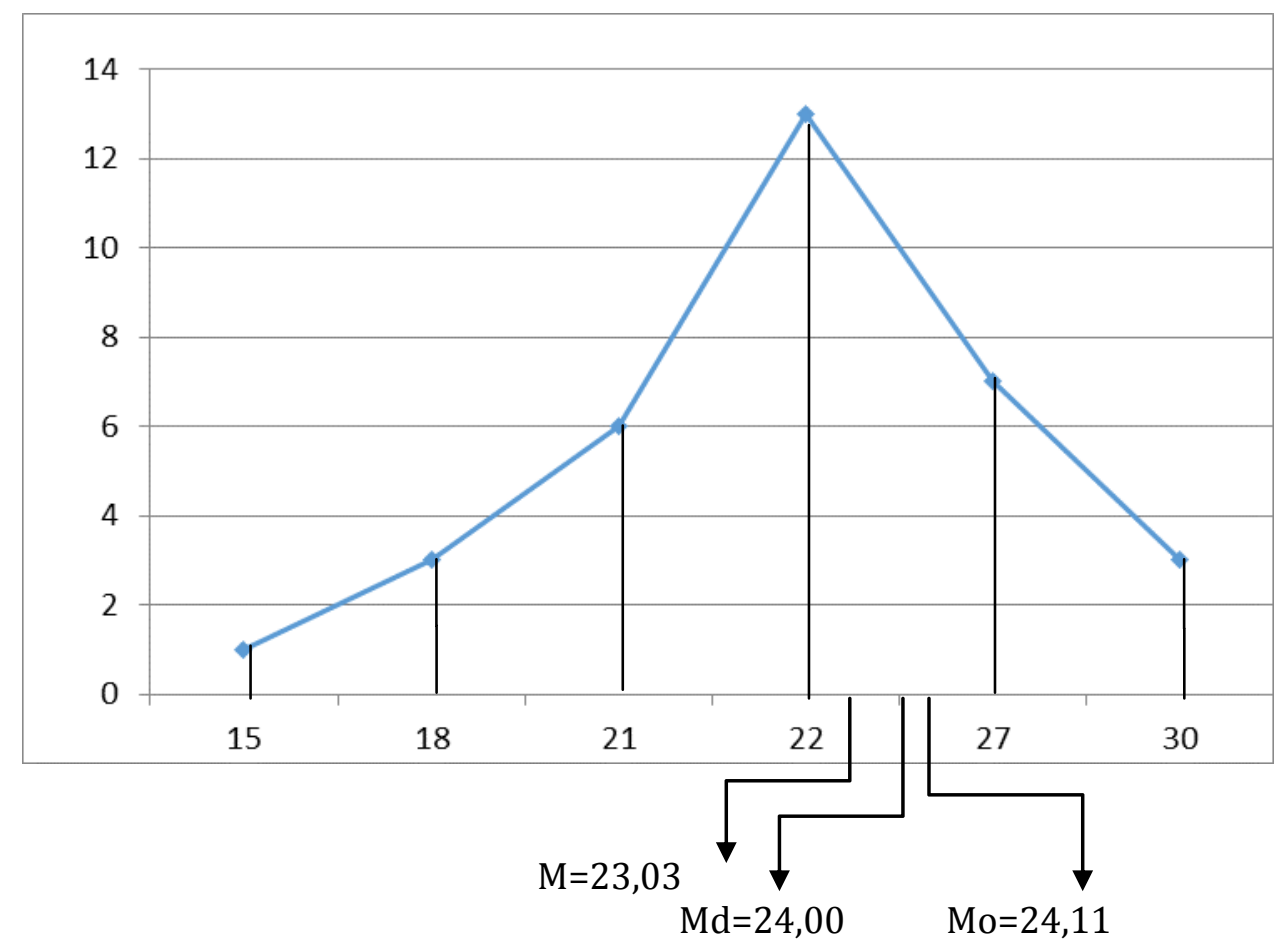

Gambar 1. Grafik Polygon Data Hasil Post-Test Kelas Eksperimen

Sedangkan deskripsi mean (M), median (Md), modus (Mo) dari data hasil belajar siswa kelas kontrol, yaitu: mean $(M)=19,83$, median $(M d)=19,60$, modus $(M o)=18,5$. Pada kelas kontrol diketahui bahwa modus lebih kecil dari median dan median lebih kecil dari mean (Mo $<\mathrm{Md}<\mathrm{M}$ ), sehingga kurva yang terbentuk adalah kurva juling positif yang artinya skor cenderung rendah. Grafik data hasil belajar eksperimen dapat dilihat pada Gambar 2.

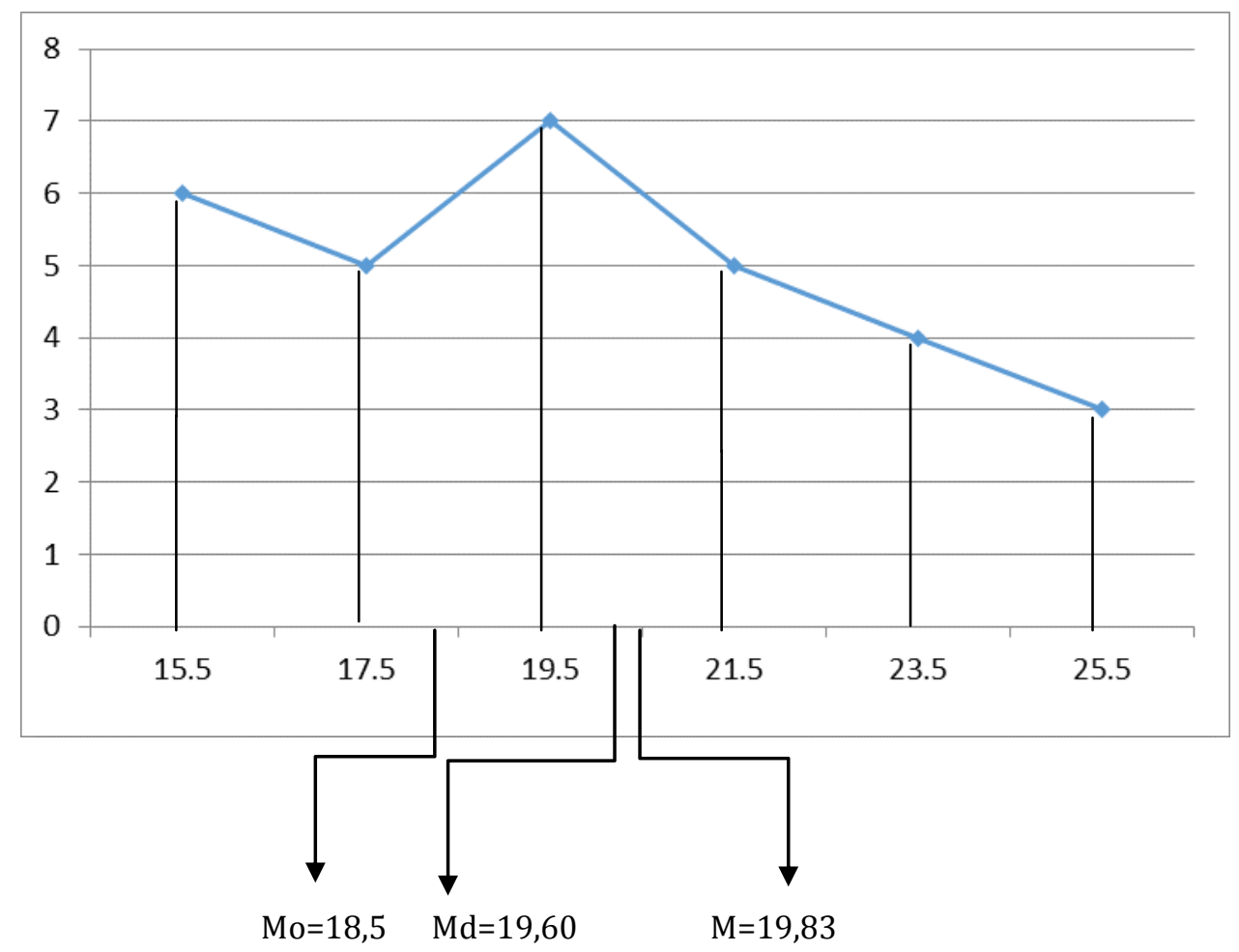

Gambar 2. Grafik Polygon Data Hasil Post-Test Kelas Kontrol 
Secara deskriptif dapat disimpulkan bahwa hasil belajar siswa yang belajar mengikuti model pembelajaran kooperatif tipe Team Games Tournament berbantuan peta konsep lebih tinggi dari siswa yang belajar mengikuti model pembelajaran konvensional.

Sebelum uji hipotesis, terlebih dahulu dilakukan pengujian prasyarat terhadap sebaran data yang meliputi uji normalitas dan homogenitas terhadap data hasil belajar IPA

siswa. Berdasarkan hasil pengujian prasyarat diperoleh bahwa data hasil belajar IPA kelas eksperimen dan kelas kontrol berdistribusi normal dan varians kedua kelas homogen, sehingga untuk menguji hipotesis menggunakan uji-t dengan rumus polled varians. Rangkuman hasil perhitungan uji-t kelas sampel disajikan pada Tabel.

Tabel 2. Rangkuman Hasil Perhitungan Uji-t

\begin{tabular}{lllllll}
\hline Data & Kelas & $\mathbf{N}$ & $\bar{X}$ & $\mathbf{s}^{\mathbf{2}}$ & $\mathbf{t}_{\text {hitung }}$ & $\mathbf{t}_{\text {tabel }}$ \\
\hline \multirow{2}{*}{ Hasil Belajar } & Eksperimen & 33 & 23,03 & 13,43 & \multirow{2}{*}{14,4} & 1,98 \\
& Kontrol & 30 & 19,83 & 11,13 & & \\
\hline
\end{tabular}

Berdasarkan Tabel 2, diperoleh $t_{\text {hitung }}$ sebesar 14,4 sedangkan $t_{\text {tabel }}\left(d b=n_{1}+n_{2}-2=33+30-2=\right.$ 61) pada taraf signifikan $5 \%$ adalah 1,98 . Hal ini berarti $t_{\text {hitung }}$ lebih besar dari $t_{\text {tabel }}\left(t_{\text {hitung }}>t_{\text {tabel }}\right)$ sehingga $\mathrm{H}_{0}$ ditolak dan $\mathrm{H}_{1}$ diterima. Dengan demikian, dapat disimpulkan bahwa terdapat perbedaan yang signifikan hasil belajar IPA antara kelompok siswa yang dibelajarkan dengan penerapan model pembelajaran kooperatif tipe Team Games Tournament (TGT) berbantuan peta konsep dengan kelompok siswa yang dibelajarkan dengan menggunakan model pembelajaran konvensional pada siswa kelas $\mathrm{V}$ Gugus VI Kecamatan Sukasada Kabupaten Buleleng Tahun pelajaran 2016/2017.

Berdasarkan hasil penelitian yang diperoleh, terdapat perbedaan hasil belajar IPA yang signifikan antara kelompok siswa yang dibelajarkan dengan model pembelajaran kooperatif tipe Team Games Tournament berbantuan peta konsep dan kelompok siswa yang dibelajarkan dengan model pembelajaran konvensional. Sejalan dengan hal tersebut, terlihat bahwa model pembelajaran kooperatif tipe Team Games Tournament berbantuan peta konsep dapat memberikan pengaruh yang lebih baik dibandingkan dengan model pembelajaran konvensional. Adapun beberapa alasan yang dapat dijadikan dasar penentuan bahwa model pembelajaran kooperatif tipe Team Games Tournament berbantuan peta konsep lebih baik dalam peningkatan hasil belajar yang lebih maksimal dibandingkan dengan model pembelajaran konvensional adalah sebagai berikut.

Pertama, dilihat dari segi landasan teoretis, model pembelajaran kooperatif tipe Team Games Tournament berbantuan peta konsep didasarkan pada pandangan konstruktivisme yang memberikan kesempatan kepada siswa untuk mengkonstruksi sendiri pengetahuannya berdasarkan pengetahuan awal yang telah dimiliki. Siswa secara aktif menggali sendiri pengetahuannya berdasarkan pengetahuan awal yang telah dimiliki dalam menyelesaikan suatu permasalahan. Permasalahan yang diberikan juga terkait dengan keadaan kontekstual siswa sehingga siswa akan merasa lebih tertantang dan membangkitkan rasa ingin tahu siswa untuk menyelesaikan permasalahan tersebut. Dalam mencari kebenaran dari penyelesaian permasalahan, siswa diberikan kesempatan untuk mengkonstruksi pengetahuannya dan memperbaiki miskonsepsi melalui pengamatan yang dilakukan secara langsung terhadap suatu permasalahan yang diberikan. Dalam hal ini siswa akan menemukan sendiri kebenaran dari suatu konsep yang dipelajari sehingga siswa akan lebih paham dan lebih ingat mengenai konsep baru yang telah dipelajari. Hal ini sesuai dengan pendapat Trianto (2007) yang menyatakan bahwa belajar merupakan kegiatan aktif siswa membangun sendiri pengetahuan dalam benaknya. Siswa harus menemukan sendiri dan mentransformasikan informasi kompleks, mengecek informasi baru sesuai dengan pengetahuan awal dan merevisinya apabila pengetahuan awal itu tidak sesuai.

Pembelajaran dengan menggunakan model kooperatif tipe Team Games Tournament (TGT) berbantuan peta konsep merupakan suatu kegiatan pembelajaran yang mudah diterapkan, melibatkan aktivitas seluruh siswa tanpa harus ada perbedaan status, melibatkan peran siswa sebagai tutor sebaya dan mengandung unsur-unsur permainan dan reinforcement, dimana dalam proses pembelajarannya dibantu dengan menggunakan media peta konsep yang akan membangkitkan perhatian dan minat siswa dalam mengikuti proses pembelajaran. Penggunaan peta konsep akan membantu siswa melihat makna materi pelajaran secara lebih komprehensif dalam setiap komponen-komponen konsep dan memudahkan siswa mengingat pokok-pokok materi yang diberikan oleh guru. Sehubungan dengan hal itu, Munthe (2009) menyatakan bahwa peta konsep dapat memfasilitasi hubungan yang lebih sepadan antara guru dan siswa. Proses pemetaan konsep dapat memberi siswa sejumlah kemerdekaan dan mengurangi kemungkinan siswa melawan, menyabotase, tergantung, dan pasif dalam proses pembelajaran. 
Kedua, dilihat dari operasional empiris dalam penyajian pembelajaran, kelompok siswa yang belajar menggunakan model pembelajaran kooperatif tipe Team Games Tournament (TGT) berbantuan peta konsep difasilitasi dengan Lembar Kerja Siswa (LKS) yang sifatnya mengembangkan daya kreativitas siswa. LKS yang disajikan dalam model pembelajaran TGT menekankan pada aktivitas siswa melalui langkah-langkah pembelajaran: a) presentasi di kelas. Materi dalam Teams Games Tournament pertamatama dikenalkan dalam presentasi di dalam kelas. Ini merupakan pengajaran langsung, seperti yang sering kali dilakukan atau diskusi pelajaran yang dipimpin oleh guru. Bedanya presentasi kelas dengan pengajaran hanyalah bahwa presentasi tersebut harus benar-benar berfokus pada unit Team Games Tournament, b) tim. Tim terdiri dari empat atau lima siswa yang mewakili seluruh bagian dari kelas dalam hal kinerja akademik, jenis kelamin dan ras. Fungsi utama dari tim ini adalah memastikan bahwa semua anggota tim benar-benar belajar, c) game. Game ini terdiri atas pertanyaan-pertanyaan yang kontennya relevan yang dirancang untuk menguji pengetahuan siswa yang diperolehnya dari presentasi di kelas dan pelaksanaan kerja tim, d) turnamen. Turnamen adalah sebuah struktur dimana game berlangsung. Turnamen biasanya berlangsung pada akhir minggu atau akhir unit, setelah guru memberikan presentasi di kelas dan tim telah melaksanakan kerja kelompok, e) rekognisi tim. Tim akan mendapatkan sertifikat atau bentuk penghargaan yang lain apabila skor rata-rata mereka mencapai kriteria tertentu.

Berbeda halnya dengan aktivitas belajar dengan menggunakan model pembelajaran konvensional, selama proses pembelajaran, guru bertindak selaku pelaksana proses pembelajaran. Umumnya yang dilakukan guru yaitu ceramah, mendemonstrasikan sesuatu, dan mendiskusikan apa yang telah dilihat atau didengar, sehingga guru lebih aktif daripada siswa karena aktivitas siswa hanya duduk, mendengarkan, mencatat, dan menghafal. Hal ini menyebabkan aktivitas siswa dalam proses pembelajaran cenderung bermain dan kurang memperhatikan penjelasan guru. Guru mendominasi pembelajaran dan siswa tidak diberikan kesempatan untuk berpendapat sesuai dengan materi pembelajaran yang sedang dipelajari. Guru memaparkan materi dengan cara lisan sehingga mengakibatkan siswa hanya mencatat beberapa hal yang disampaiakan oleh guru. Kebanyakan siswa tidak memiliki catatan pada saat proses pembelajaran berlangsung, hal ini diakibatkan karena guru terlalu cepat menyampaikan materi tanpa memberikan penekanan-penekanan pada pokok materi kepada siswa, dengan pembelajaran seperti ini maka akan berpengaruh terhadap hasil belajar siswa. Hal ini mengakibatkan hasil belajar siswa yang dibelajarkan menggunakan model konvensional lebih rendah dibandingkan siswa yang dibelajarkan menggunakan model Team Games Tournament berbantuan peta konsep. Tinjauan ini didasarkan pada perolehan rata-rata skor hasil belajar IPA antara kelompok siswa yang belajar menggunakan model pembelajaran Team Games Tournament berbantuan peta konsep dan kelompok siswa yang belajar menggunakan model pembelajaran konvensional. Rata-rata skor hasil belajar IPA kelompok siswa yang dibelajarkan dengan model pembelajaran Team Games Tournament berbantuan peta konsep adalah 23,03 berada pada kategori sangat tinggi. Sedangkan rata-rata skor hasil belajar IPA siswa kelompok kontrol yang dibelajarkan dengan model pembelajaran konvensional adalah 19,83. Jika skor hasil belajar IPA siswa kelompok eksperimen digambarkan dalam grafik polygon tampak bahwa kurve sebaran data merupakan juling negatif yang artinya sebagian besar skor hasil belajar IPA siswa cenderung tinggi. Hal ini berbanding terbalik dengan kelompok kontrol, jika skor hasil belajar IPA siswa digambarkan dalam grafik polygon tampak bahwa kurve sebaran data merupakan juling positif yang artinya sebagian besar skor hasil belajar IPA siswa cenderung rendah.

Hal ini senada dengan beberapa hasil penelitian sebelumnya, yang mengungkapkan bahwa model pembelajaran Team Games Tournament efektif digunakan dalam pembelajaran. Beberapa keunggulan model pembelajaran Team Games Tournament tersebut didukung oleh hasil penelitian yang dilakukan oleh Hamid (2014) yang menyatakan bahwa model pembelajaran TGT dapat meningkatkan hasil belajar IPA Biologi pada siswa kelas VIII ${ }^{\mathrm{A}}$ MTs Negeri Dowora Kota Tidore Kepulauan. Hal ini dibuktikan dengan adanya peningkatan hasil belajar siswa antara siklus I dan siklus II. Tes siklus I diperoleh nilai 47,83\%, dan saat dilakukan tes pada siklus II terdapat peningkatan hasil belajar dengan nilai 86,96\%.

Berdasarkan keseluruhan pemaparan di atas, dapat diinterpretasikan bahwa hasil penelitian ini menunjukkan terdapat perbedaan yang signifikan terhadap kemampuan hasil belajar siswa antara kelompok siswa yang dibelajaran dengan model pembelajaran kooperatif tipe Team Games Tournament (TGT) berbantuan peta konsep dengan kelompok siswa yang dibelajarkan dengan model pembelajaran konvensional pada mata pelajaran IPA kelas V SD di Gugus VI Kecamatan Sukasada Kabupaten Buleleng Tahun Pelajaran 2016/2017. Dengan demikian, model pembelajaran kooperatif tipe Team Games Tournament (TGT) berbantuan peta konsep berpengaruh positif terhadap hasil belajar siswa 


\section{Simpulan dan Saran}

Berdasarkan hasil pengujian hipotesis dan pembahasan, ditemukan bahwa terdapat perbedaan yang signifikan hasil belajar IPA antara siswa kelas $\mathrm{V}$ yang belajar mengikuti model pembelajaran Team Games Tournament (TGT) berbantuan peta konsep dan siswa kelas V yang belajar mengikuti model pembelajaran konvensional SD Gugus VI Kecamatan Sukasada Tahun Pelajaran 2016/2017. Hal ini dapat dilihat pada perhitungan pengujian hipotesis melalui uji-t, dinyatakan bahwa thitung $>$ ttabel (thitung $=$ 14,4 $>$ ttabel $=1,98$, sehingga H0 ditolak dan H1 diterima. Berdasarkan rata-rata skor hasil belajar IPA, diketahui bahwa skor rata-rata siswa kelas $\mathrm{V}$ yang belajar mengikuti model pembelajaran Team Games Tournament (TGT) berbantuan peta konsep adalah 23,03 (dikategorikan sangat tinggi), sedangkan ratarata skor siswa kelas V yang belajar mengikuti model pembelajaran konvensional adalah 19,83 (dikategorikan tinggi). Dengan demikian, dapat disimpulkan bahwa pembelajaran dengan menggunakan model pembelajaran Team Games Tournament (TGT) berbantuan peta konsep berpengaruh positif terhadap hasil belajar IPA siswa kelas V SD Gugus VI Kecamatan Sukasada Tahun Pelajaran 2016/2017. Saran yang dapat diajukan berdasarkan penelitian yang telah dilakukan adalah sebagai berikut. Secara teoretis, disarankan model pembelajaran kooperatif tipe Team Games Tournament berbantuan peta konsep dapat dijadikan sebagai bahan bacaan terutama bagi guru untuk dapat memperluas pengetahuan serta meningkatkan pemahaman tentang penerapan model pembelajaran yang inovatif. Saran-saran tersebut dipaparkan dalam penjelasan berikut. 1) Disarankan kepada peserta didik, dengan model pembelajaran kooperatif tipe Team Games Tournament berbantuan peta konsep diharapkan siswa dapat meningkatkan rasa percaya diri untuk berpendapat dalam menjawab pertanyaan, sehingga dapat menambah wawasan siswa dalam pengetahuannya agar mampu meningkatkan hasil belajar secara maksimal. 2) Disarankan kepada guru, dengan model pembelajaran kooperatif tipe Team Games Tournament berbantuan peta konsep dapat dijadikan salah satu alternatif dalam menggunakan model pembelajaran dan media pembelajaran pada mata pelajaran IPA ataupun pada mata pelajaran lain yang sejenis untuk mempermudah guru dalam menyampaikan materi pelajaran, sehingga siswa cepat memahami dan mengerti materi yang disampaikan. 3) Disarankan kepada kepala sekolah, sebagai acuan dalam mengambil kebijakan untuk mengusahakan peningkatan kualitas mutu pendidikan di sekolah dengan memberikan bimbingan kepada guru-guru terutama dalam menggunakan model pembelajaran yang inovatif. 4) Disarankan kepada peneliti lain agar dapat menggunakan hasil penelitian ini sebagai acuan kepustakaan dalam melakukan penelitian baik dalam variabel yang sama ataupun variabel yang berbeda.

\section{Daftar Rujukan}

Agung, A. A. Gede. 2014. Metodologi Penelitian Pendidikan. Singaraja: Fakultas Ilmu Pendidikan, Universitas Pendidikan Ganesha.

Bundu, Patta. 2006. Penilaian Keterampilan Proses dan Sikap Ilmiah (Dalam Pembelajaran Sains Sekolah Dasar). Jakarta: Departemen Pendidikan Nasional.

Dantes, Nyoman. 2012. Metode Penelitian. Yogyakarta: C.V Andi Offset.

Dewi, I. A. Kd. Novia Puspita. 2017. “Pengaruh Model Pembelajaran Kooperatif Tipe TGT Terhadap Hasil Belajar PKn Siswa Kelas V SD". e-Journal Mimbar PGSD Universitas Pendidikan Ganesha Jurusan PGSD, Vol5, No 2.

Hamid, Saoda. 2014. Penerapan Model Pembelajaran TGT dalam Meningkatkan Hasil Belajar IPA Biologi Siswa di MTs Negeri Dowora. Jurnal Kreatif Tadulako Online (Vol:2 No:2 Tahun 2014). Diakses pada tanggal 4 Januari 2017.

Munthe, B. 2009. Desain Pembelajaran. Yogyakarta: Pustaka Insan Madani.

Putra, I Ketut Dedi Agung Susanto. 2017. Pengaruh Model Pembelajaran Inquiry Terbimbing Berbantuan Peta Pikiran Terhadap Hasil Belajar IPA Kelas V SDI. Universitas Pendidikan Ganesha: Vol 5 No 2.

Rusman. 2010. Model-model Pembelajaran: Mengembangkan Profesionalisme Guru. Bandung: PT Raja Grafindo Persada. 
Setyosari, Punaji. 2015. Metode Penelitian Pendidikan dan Pengembangan. Jakarta: Kencana Prenanda Media Group.

Saptayanti, Gusti Ayu Kadek Emi. 2016. "Pengaruh Model Pembelajaran Kooperatif Tipe TGT (Team Games Tournament) Terhadap Hasil Belajar Matematika”. e-Journal Mimbar PGSD Universitas Pendidikan Ganesha Jurusan PGSD, Vol 4, No 1.

Salam, A., Hossain, A., \& Rahman, S. 2015. Effects of using Teams Games Tournaments (TGT) Cooperative Technique for Learning Mathematics in Secondary Schools of Bangladesh. Malaysian Online Journal of Educational Technology, Vol.3 No.3, Hal. 1-11.

Slavin, Robert. 2010. Cooperative Learning Teori, Riset dan Praktik. Terjemahan Narulita Yusron. Cooperative Learning: theory, research and practice. 2005. Cetakan K-6. Bandung: Nusa Media.

Sudarmi, Yanthi Made. 2014. "Penerapan Model Pembelajaran Kooperatif Tipe Team Games Tournament (TGT) Unutk Meningkatkan Hasil Belajar Pendidikan Kewarganegaraan”. e-Journal Mimbar PGSD Universitas Pendidikan Ganesha Jurusan PGSD, Vol 2, No 1.

Sukardjo. 2012. Landasan Pendidikan Konsep dan Aplikasinya. Jakarta: PT. RajaGrafindo Persada.

Wati, Ajeng Aprina. 2015. "Pengaruh Model Pembelajaran Kooperatif Tipe TGT (Team Games Tournament) Terhadap Hasil Belajar Siswa Kelas V Tema 8di Sdn Babatan I/456 Surabaya”. Jurnal Penelitian Pendidikan Guru Sekolah Dasar Universitas Negeri Surabaya, Volume 03, Nomor 02. 